\title{
Co-Inoculation of Bacillus spp. for Growth Promotion and Iron Fortification in Sorghum
}

\author{
Mansani Manasa ${ }^{1}$, Polapally Ravinder ${ }^{1}$, Subramaniam Gopalakrishnan ${ }^{2, *} \mathbb{0}$, Vadlamudi Srinivas ${ }^{2}$, \\ R. Z. Sayyed ${ }^{3,4}{ }^{\circledR}$, Hesham Ali El Enshasy ${ }^{5,6,7}\left(\mathbb{0}\right.$, Maizatulakmal Yahayu ${ }^{5}$, Ali Tan Kee Zuan $8, * \mathbb{0}$, \\ Hazem S. Kassem ${ }^{9}$ (D) and Bee Hameeda ${ }^{1, *}$
}

check for updates

Citation: Manasa, M.; Ravinder, P.; Gopalakrishnan, S.; Srinivas, V.; Sayyed, R.Z.; El Enshasy, H.A.; Yahayu, M.; Kee Zuan, A.T.; Kassem, H.S.; Hameeda, B. Co-Inoculation of Bacillus spp. for Growth Promotion and Iron Fortification in Sorghum. Sustainability 2021, 13, 12091.

https://doi.org/10.3390/su132112091

Academic Editor: Roberto Mancinelli

Received: 17 September 2021

Accepted: 26 October 2021

Published: 2 November 2021

Publisher's Note: MDPI stays neutral with regard to jurisdictional claims in published maps and institutional affiliations.

Copyright: (C) 2021 by the authors. Licensee MDPI, Basel, Switzerland. This article is an open access article distributed under the terms and conditions of the Creative Commons Attribution (CC BY) license (https:/ / creativecommons.org/licenses/by/ $4.0 /)$.
1 Department of Microbiology, Osmania University, Hyderabad 500007, India; logontomanasa@gmail.com (M.M.); ravi.pp54@gmail.com (P.R.)

2 International Crops Research Institute for the Semiarid Tropics (ICRISAT), Hyderabad 502324, India; ijbbs2011@gmail.com

3 Department of Microbiology, PSGVP Mandal's Arts, Science, Commerce College, Shahada 425409, India; sayyedrz@gmail.com

4 APSSA, Department of Entomology, Auburn University, Auburn, AL 36830, USA

5 Institute of Bioproduct Development (IBD), Universiti Teknologi Malaysia (UTM), Skudai 81310, Johor, Malaysia; henshasy@ibd.utm.my (H.A.E.E.); maizatul@ibd.utm.my (M.Y.)

6 School of Chemical and Energy Engineering, Faculty of Engineering, Universiti Teknologi Malaysia (UTM), Skudai 81310, Johor, Malaysia

7 City of Scientific Research and Technology Applications (SRTA), New Burg Al Arab, Alexandria 21934, Egypt

8 Department of Land Management, Faculty of Agriculture, Universiti Putra Malaysia (UPM), Serdang 43400, Selangor, Malaysia

9 Department of Agricultural Extension and Rural Society, College of Food and Agriculture Sciences, King Saud University, Riyadh 11451, Saudi Arabia; hskassem@ksu.edu.sa

* Correspondence: s.gopalakrishnan@cgiar.org (S.G.); tkz@upm.edu.my (A.T.K.Z.); drhami2009@gmail.com (B.H.)

Abstract: Seven Bacillus spp. isolated from the marine water and the rhizosphere of the medicinal plant Coscinium fenestratum were studied to produce plant growth promotion (PGP) traits in vitro. Among the seven isolates, MMRH22 and RHPR20 produced copious amounts of PGP traits. Based on the 16S rRNA sequence, the two potent bacterial isolates, RHPR20 and MMRH22, were identified as Bacillus mojavensis and Bacillus cereus, respectively. A compatibility test between the isolates RHPR20 and MMRH22 revealed they are compatible and can be used as a consortium. Both isolates were evaluated for the plant growth promotion and the biofortification of sorghum under greenhouse conditions. Treatments included the application of MMRH22, RHPR20, their consortium (RHPR20 + MMRH22), and an uninoculated control. Inoculation with bacterial cultures resulted in a significant increase in the plant height; the number of leaves; the leaf area; the root, shoot, and leaf weight; and the yield of sorghum at 30 and 60 days after sowing (DAS). The scanning electron micrograph of the sorghum plant roots revealed extensive colonization in the plants treated with the bacterial cultures compared to the uninoculated control. The sorghum grains obtained after final harvest were analyzed for their nutrient content by ICP-OES. The biofortification in sorghum grains was varied and was found to enhance the iron content up to $97 \%$. This study revealed that treatments with microbial consortia enhance plant growth, yield, and iron content, which could combat nutrient deficiencies in plants and humans.

Keywords: Bacillus; consortium; sorghum; plant growth promotion; biofortification

\section{Introduction}

Iron deficiency is highly prevalent among the global population, and it can result in iron deficiency anemia (IDA), impairment in physical activity, mental retardation, child death, and stillbirth. Iron deficiency arises due to the lack of adequate iron in the soil 
and the edible parts of plants, such as vegetables and fruits, and reduced iron uptake by plants. This problem can be addressed by using nutrient supplements or through the biofortification of crop plants with rhizobacteria. This approach is a sustainable alternative to counter nutrient deficiencies [1,2].

Sorghum is one of the most important cereal crops that occupy the fifth position globally [3]. It is the dietary staple food for around 500 million people in more than 30 countries. In addition, sorghum is also used as an animal feed, in the production of biofuels, in the creation of alcoholic beverages [4-6], etc. It is a gluten-free food, and its consumption is known to mitigate blood glucose levels [7]. Low yield in sorghum is usually attributed to the inaccessibility of required nutrients and iron to the plants. The use of plant growth-promoting rhizobacteria (PGPR) to secrete organic acids and iron-chelating agents can be the best alternative to chemical fertilizer [8]. Therefore, it is time to analyze sorghum-microbe interactions for yield and nutrient uptake.

PGPR with the ability to solubilize various nutrients in the soil might serve as an alternative to chemical fertilizers and supplements commonly used to improve nutrient content in crops $[9,10]$. PGPR promotes plant growth directly by producing indole acetic acid (IAA) and other hormones as well as indirectly by inducing systemic resistance to phytopathogens [11,12]. In order to meet the iron requirements, microorganisms release siderophores that chelate insoluble iron and aid in the uptake of iron siderophore complexes by plants [13]. Siderophore-producing bacteria enable iron nutrition in plants by competing with the pathogenic bacteria for Fe (III) in the rhizosphere, which leads to the death of the pathogen and enhances iron uptake by plants [8]. Marine microbes can adapt to a wide range of pressure, temperature, salinity, $\mathrm{pH}$, and nutrient conditions. They are known to produce around 10,000 metabolites including antibiotics, biosurfactants, peptides, vitamins, and enzymes [14]. The use of marine bacteria for plant growth promotion (PGP) helps plants to adapt to drought and salt-stress conditions [15]. In the past few decades, PGPR that belong to the species of Bacillus isolated from the rhizosphere and marine sources have been used for plant growth promotion. The Bacillus species are preferred for their use in agriculture due to their ability to produce bioactive metabolites and endospores to withstand biotic and abiotic stress conditions, which thereby promote plant growth and nutrient uptake [16-19]. In the present study, Bacillus spp., isolated from marine water and the rhizosphere, were evaluated for improvement in growth, yield, and iron content in sorghum under in vitro and in vivo conditions. In addition, the ability of the isolates to colonize sorghum roots was also tested.

\section{Materials and Methods}

\subsection{Selection of Bacillus spp. from Available Germplasm}

Bacillus spp. MMRH22, KSRH1, KSRH7, and KSRH34 used in the present study were isolated from marine water samples and RHPR20, RHPR22, and RHPR24 from rhizosphere samples, maintained as a germplasm collection at our lab and used for further characterization in the present study.

\subsection{In Vitro Analysis of Plant Growth-Promoting Traits}

All seven bacterial isolates obtained were tested for PGP traits like indole acetic acid (IAA), ammonia, HCN, 1-aminocyclopropane-1-carboxylate (ACC) deaminase, and solubilization of phosphate and zinc.

Assay for IAA was performed in a nutrient broth medium supplemented with $5 \mathrm{mM}$ L-tryptophan and incubated for $48 \mathrm{~h}$. After incubation, Salkowski reagent $(50 \mathrm{~mL}$ of $35 \% \mathrm{HClO}_{4}$ and $1 \mathrm{~mL}$ of $0.5 \mathrm{M} \mathrm{FeCl}_{3}$ ) was added, and then absorbance was measured at $530 \mathrm{~nm}[20]$.

Phosphate and zinc solubilization was evaluated on NBRIP (National Botanical Research Institute's phosphate growth) medium [21] containing tricalcium phosphate as insoluble phosphorous, and Bunt-Rovira medium containing $0.1 \%$ zinc oxide and zinc 
carbonate as an insoluble zinc source [22], respectively. Quantification of phosphate solubilization was done by the ammonium phosphomolybdate method [23].

Ammonia production by bacterial cultures was assayed in a peptone water medium (Peptone $1 \%, \mathrm{NaCl} 0.5 \%$ ), and incubated for $48 \mathrm{~h}$ at $37^{\circ} \mathrm{C}$ in a shaker incubator. Ammonium accumulation was tested by adding $0.1 \mathrm{~mL}$ Nessler's reagent and observed for the development of yellow-brown color [24].

Production of $\mathrm{HCN}$ was analyzed by picrate assay on nutrient agar plates amended with glycine $(4.4 \mathrm{~g} / \mathrm{L})$ and filter paper impregnated with $0.5 \%$ picric acid solution prepared with $2 \%$ sodium carbonate followed by incubation at $37^{\circ} \mathrm{C}$ for $24-48 \mathrm{~h}$. Change in color from orange red to brown indicates a positive for $\mathrm{HCN}$ production [25].

ACC deaminase activity was done by inoculating Bacillus spp. in nitrogen-free broth amended with $3 \mathrm{mM}$ ACC (Sigma-Aldrich, St. Louis, MO, USA) as the sole source of nitrogen. Cultures were grown in tryptone soya broth for $24 \mathrm{~h}$ at $37^{\circ} \mathrm{C}$ and centrifuged at 10,000 rpm for $10 \mathrm{~min}$. Pellets were washed thrice with saline and re-suspended in $1 \mathrm{~mL}$ saline. This was spot inoculated on Burk's agar medium supplemented with $3 \mathrm{mM}$ ACC as the sole nitrogen source. Burk's medium with $0.2 \%$ ammonium sulfate served as a positive control, and the same medium without ACC and ammonium sulfate was used as a negative control. Cultures were incubated for 7 days at $37^{\circ} \mathrm{C}$, and differences in growth patterns on ACC-amended plates compared to positive and negative controls were recorded [26].

Bacillus spp. were evaluated for the production of siderophores by chrome azurol s (CAS) shuttle assay as described by Schwyn and Neilands [27]. In brief, all the bacterial cultures were grown in King's B broth medium for $48 \mathrm{~h}$ at $37^{\circ} \mathrm{C}$ on a rotary shaker $(120 \mathrm{rpm}$ ) and then centrifuged at $8000 \mathrm{rpm}$ for $10 \mathrm{~min}$. A total of $2 \mathrm{~mL}$ of CAS assay solution was added to $1 \mathrm{~mL}$ of the supernatant and incubated at room temperature in dark conditions. Simultaneously, a blank was prepared using King's B broth medium and CAS assay solution. Absorbance was measured at $630 \mathrm{~nm}$, and the percentage of siderophore units was calculated using the following formula.

$$
\% \text { Siderophore }=\frac{(\mathrm{Ar}-\mathrm{As})}{\mathrm{Ar}} \times 100
$$

where Ar is the absorbance of blank and As is the absorbance of the culture supernatant.

\subsection{Screening for Production of Extracellular Enzymes: Protease, Cellulase, and Amylase}

Protease production was identified by inoculation of actively grown bacterial cultures on casein-agar (casein $30 \mathrm{~g} / \mathrm{L}$, agar $20 \mathrm{~g} / \mathrm{L}$ ) and incubated at $37^{\circ} \mathrm{C}$ for $48 \mathrm{~h}$ [20]. The formation of a halo zone around the colonies indicated the production of protease.

Cellulase production was tested by spot inoculation of Bacillus spp. onto sterilized filter paper discs placed on cellulose-Congo red agar (cellulose, $1 \%$; $\mathrm{K}_{2} \mathrm{HPO}_{4}, 0.009 \%$; $\mathrm{KCl}, 0.01 \% ; \mathrm{MgSO}_{4}, 0.0049 \%$; and agar 2\%) [28]. Formation of halo zones around colonies indicated the production of cellulase.

Starch hydrolysis was tested by inoculating a loopful of bacterial culture on starchagar plates (soluble starch, $20 \mathrm{~g} / \mathrm{L}$; peptone, $5 \mathrm{~g} / \mathrm{L}$; meat extract, $3 \mathrm{~g} / \mathrm{L}$; and agar $20 \mathrm{~g} / \mathrm{L}$ ). Plates were incubated at $37^{\circ} \mathrm{C}$ for $48 \mathrm{~h}$ and flooded with Gram's iodine [29]; the formation of clear halo zones around colonies indicated it was positive for amylase production.

\subsection{Molecular Identification of Potential Bacterial Isolates}

Based on PGP traits characterized above, two potential Bacillus spp. MMRH22 and RHPR20 were identified using a 16S rRNA sequence (Macrogen, Korea). The resemblance of the sequence to the species was analyzed by NCBI BLAST, submitted to NCBI, and accession numbers were obtained. The phylogenetic tree was constructed by MEGA X software. 


\subsection{Compatibility Studies}

Compatibility test was performed by streaking cultures so that each bacterial culture comes in contact with the other, i.e., radiating from the center. Plates were incubated for $48 \mathrm{~h}$ at $37^{\circ} \mathrm{C}$ and observed for growth [30]. Based on PGP traits and compatibility studies, both Bacillus spp. RHPR20 and MMRH22 were used for plant growth studies.

\subsection{Plant Growth Promotion under Greenhouse Conditions}

Sorghum seeds (PVK 801; maturity time: 110 days) were acquired from the sorghum breeding center at International Crops Research Institute for the Semi-Arid Tropics (ICRISAT), in Patancheru, Hyderabad, India, and greenhouse studies were done at the same location. Soil mixture for pots was prepared by mixing black soil (Vertisol), sand, and compost in a ratio of 3:2:1. A total of four treatments (RHPR20, MMRH22, consortium (RHPR20 + MMRH22), and uninoculated control) was maintained in twelve replications, out of which six replications were performed in 6 inchespots ( 3 harvested at 30 days after sowing (DAS) and 3 harvested at 60 DAS) and remaining six replications in 8 inches pots (harvested after crop maturity). Seeds were surface sterilized with $2 \%$ sodium hypochlorite $(\mathrm{NaOCl})$ for $2 \mathrm{~min}$ and washed with sterilized distilled water 7 times. After this, seeds were treated with $70 \%$ ethanol for $1 \mathrm{~min}$ followed by sterilized distilled water 6 times. Surface sterilized seeds were incubated with respective bacterial cultures (grown in nutrient broth) of each treatment for $60 \mathrm{~min}$ before sowing. In control, sterilized distilled water was used to soak seeds. Four seeds were sown in each $6 "$ pots and six seeds in 8 " pots which were thinned to two and three plants after germination. A booster dose of Bacillus cultures (107 CFU; in case of consortia, booster dose was given by mixing equal quantities of both cultures) each at a concentration of $10 \% v / v$ (mixed with water) was added to pots every fifteen days after germination till flowering. Based on the growth stage of plants, various parameters like plant height, number of leaves, leaf area, root, shoot, leaf, panicle, and seed weight were recorded.

\subsection{Root Colonization by Bacillus spp.}

Sorghum seeds (PVK 801) were surface-sterilized and treated with bacterial cultures (RHPR20, MMRH22, consortium (RHPR20 + MMRH22), and uninoculated control) as described above and sown in pots (4 inches) containing sterile coarse sand. Pots were incubated in the greenhouse for 15 days, and the root tips of the plants were harvested using sterile blades. These root tips were fixed in $2 \%$ glutaraldehyde-phosphate buffered saline overnight at $4{ }^{\circ} \mathrm{C}$ and postfixed in osmium tetroxide. Processed roots were coated with a gold layer using a sputter coater and scanned under a scanning electron microscope (SEM) (Hitachi S-3700N) at the University College of Technology, Osmania University, Hyderabad [31].

\subsection{Estimation of Iron ( $\mathrm{Fe}$ ) Content of Sorghum Grains}

Sorghum grains obtained after harvest were dried in a hot air oven at $45{ }^{\circ} \mathrm{C}$ for three days, ground to fine powder at room temperature. The flour obtained thus was digested with $\mathrm{HNO}_{3}$ and $\mathrm{H}_{2} \mathrm{O}_{2}$ as per AOAC [32] standards. Micronutrient concentration in these digested samples was estimated using inductively coupled plasma-optical emission spectroscopy (ICP-OES) by running against known standards.

\subsection{Statistical Analysis}

Data obtained in greenhouse studies were analyzed using ANOVA (GenStat 10.1 version) with LSD at $5 \%$.

\section{Results}

\subsection{In Vitro Analysis for Plant Growth-Promoting Traits}

All seven Bacillus spp. were positive for the production of IAA on plates. However, variations were observed in the quantity of IAA produced by each isolate. The highest 
IAA $(197 \mu \mathrm{g} / \mathrm{mL})$ was produced by the isolate RHPR20, whereas the lowest $(86.3 \mu \mathrm{g} / \mathrm{mL})$ was by KSRH7 (Table 1). Similarly, the rhizosphere and marine isolates showed phosphate solubilization on the NBRIP medium by forming a halo zone around the colonies from the secretion of organic acids. The highest solubilization of phosphate was observed with the rhizosphere isolate RHPR20 $(252.4 \mu \mathrm{g} / \mathrm{mL})$ and the marine isolate MMRH22 $(180.76 \mu \mathrm{g} / \mathrm{mL})$. In contrast, out of the seven isolates, only two (RHPR20 and MMRH22) showed positive results for zinc solubilization that was indicated by a halo zone forming around the colonies. Out of the two isolates, MMRH22 showed the highest zone of solubilization $(30 \mathrm{~mm})$, followed by RHPR20 $(10 \mathrm{~mm})$ (Table 1). All Bacillus spp. showed positive results for the production of ammonia and ACC deaminase (Table 1). Siderophore production by Bacillus MMRH22 was the highest (64.3), followed by RHPR20 (59.8), RHPR22 (47.2), KSRH34 (46.8), KSRH1 (40.3), RHPR24 (40.3), and the least was by KSRH7 (18.3) (Table 1).

Table 1. PGP traits of bacterial isolates obtained from rhizosphere and marine samples.

\begin{tabular}{|c|c|c|c|c|c|c|}
\hline Isolate & $\begin{array}{c}\text { IAA } \\
\text { Production } \\
(\mu \mathrm{g} / \mathrm{mL})\end{array}$ & $\begin{array}{c}\text { Phosphate } \\
\text { Solubilization } \\
(\mu \mathrm{g} / \mathrm{mL})\end{array}$ & $\begin{array}{c}\text { Zinc } \\
\text { Solubilization }\end{array}$ & $\begin{array}{l}\text { Ammonia } \\
\text { Production }\end{array}$ & $\begin{array}{c}\text { ACCD } \\
\text { Production }\end{array}$ & $\begin{array}{l}\text { Siderophore } \\
\text { Production }\end{array}$ \\
\hline KSRH1 & 97.8 & 147.61 & - & ++ & +++ & 40.3 \\
\hline KSRH7 & 86.3 & 170.19 & - & + & + & 18.3 \\
\hline MMRH22 & 173 & 180.76 & $30 \mathrm{~mm}$ & +++ & +++ & 64.3 \\
\hline KSRH34 & 169 & 145.65 & - & + & ++ & 46.8 \\
\hline RHPR20 & 197 & 252.4 & $10 \mathrm{~mm}$ & +++ & +++ & 59.8 \\
\hline RHPR22 & 84 & 84.32 & - & + & +++ & 47.2 \\
\hline RHPR24 & 113 & 56.3 & - & ++ & + & 40.3 \\
\hline
\end{tabular}

Marine isolates MMRH and KSRH; Rhizosphere isolate RHPR; +, ++, and +++ indicate weak, moderate, and heavy producers, respectively.

\subsection{Screening for Production of Extracellular Enzymes: Protease, Cellulase, and Amylase}

The production of extracellular enzymes by the tested Bacillus isolates is depicted in Table 2. The highest protease, amylase, and cellulase enzymes were observed in MMRH22 and RHPR20, followed by KSRH7 and RHPR24, then KSRH34, and the least by KSRH1 and RHPR22.

Table 2. Screening for the production of extracellular enzymes by bacterial isolates.

\begin{tabular}{cccc}
\hline \multirow{2}{*}{ Isolate } & \multicolumn{3}{c}{ Production of Extracellular Enzymes } \\
\cline { 2 - 4 } & Protease & Amylase & Cellulase \\
\cline { 2 - 4 } KSRH1 & + & + & + \\
KSRH7 & ++ & + & ++ \\
MMRH22 & +++ & +++ & +++ \\
KSRH34 & + & ++ & + \\
RHPR20 & +++ & +++ & +++ \\
RHPR22 & + & + & + \\
RHPR24 & ++ & + & ++ \\
\hline
\end{tabular}

,,+++ and +++ indicate weak, moderate, and heavy producers, respectively.

\subsection{Molecular Identification of Potential Bacterial Isolates}

Based on the results of the PGP traits, two potential Bacillus isolates, RHPR20 and MMRH22, were identified by a $16 \mathrm{~S}$ rRNA gene sequence. The sequences obtained were aligned against similar sequences in GenBank, and the results revealed that RHPR20 was similar to Bacillus mojavensis and MMRH22 was similar to Bacillus cereus. Both sequences were submitted to the NCBI, and the accession numbers obtained were MH211387 for Bacillus mojavensis RHPR20 and MW397137 for Bacillus cereus MMRH22. The phylogenetic trees of both the isolates are depicted in Figures 1 and 2. 


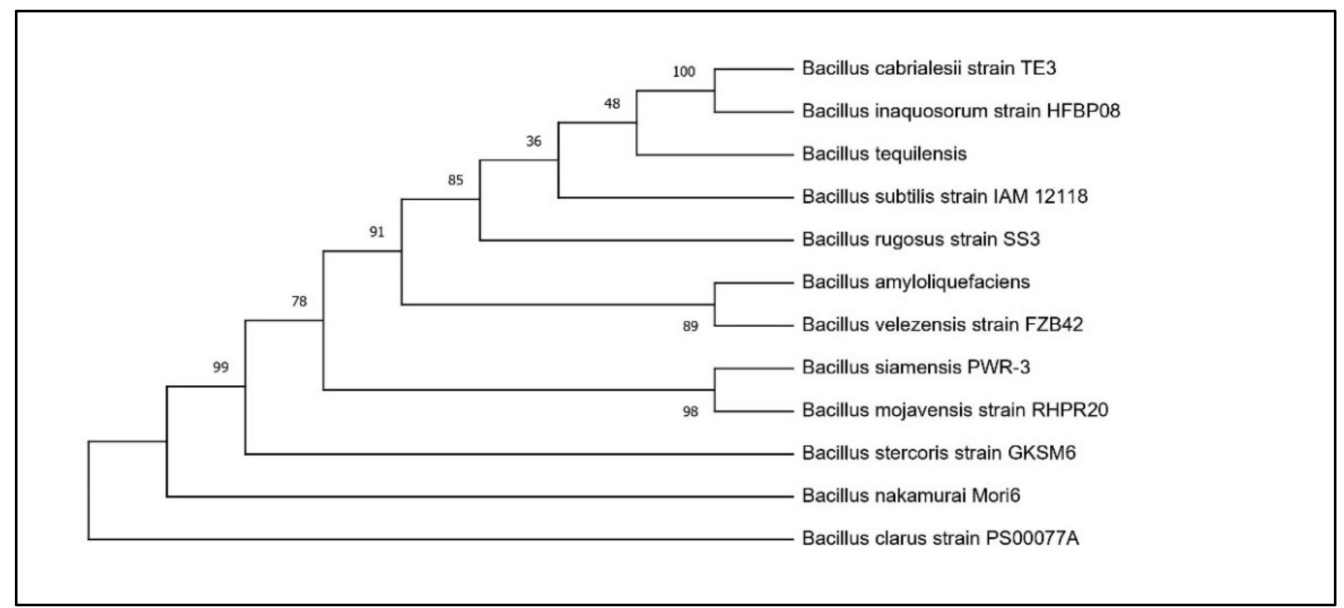

Figure 1. Phylogenetic tree of Bacillus mojavensis RHPR20.

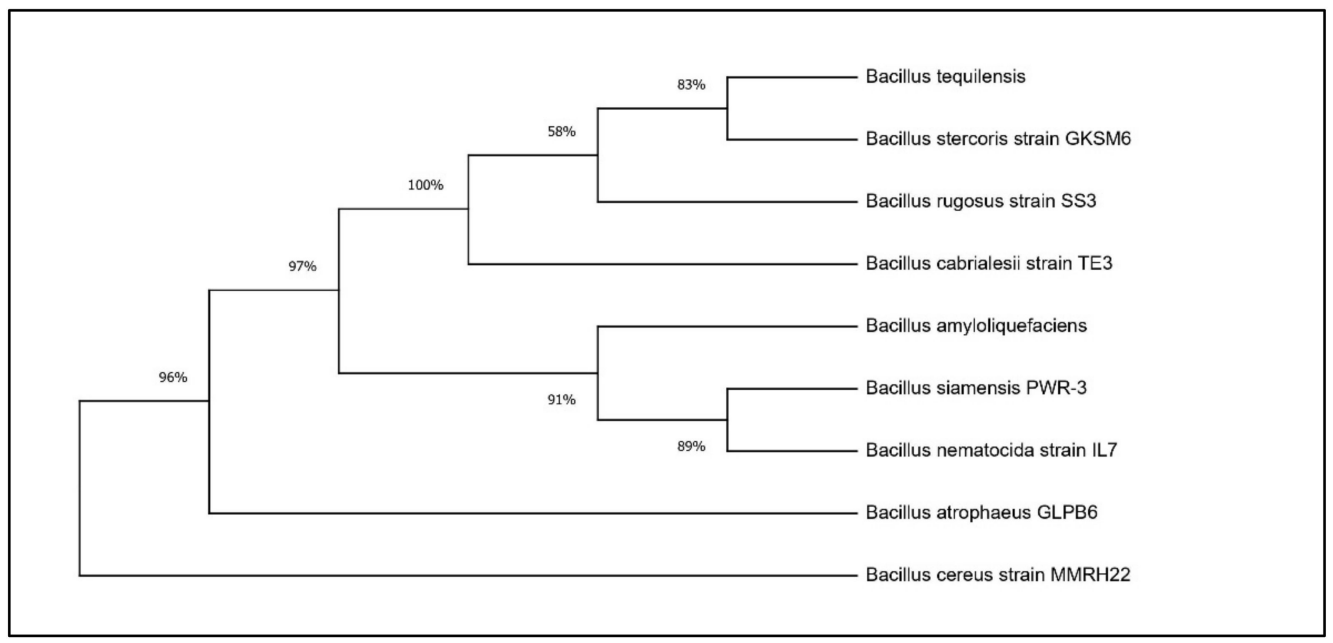

Figure 2. Phylogenetic tree of Bacillus cereus MMRH22.

\subsection{Compatibility Studies}

The potential isolates B. mojavensis RHPR20 and B. cereus MMRH22 were tested for their compatibility to evaluate them as consortia for plant growth studies. There was no inhibition zone in the vicinity of both isolates, which indicated that they were compatible with each other (Figure 3). Although there was no inhibition at the interaction point of the two isolates, the growth of Bacillus mojavensis RHPR20 was faster than Bacillus cereus MMRH22.

\subsection{Plant Growth Promotion under Greenhouse Conditions}

Based on in vitro PGP characteristics, Bacillus mojavensis RHPR20, Bacillus cereus MMRH22, and their consortia were assessed for the growth promotion of sorghum under greenhouse conditions. A significant increase in the growth of the sorghum seedlings was observed in all the treatments, as compared to the uninoculated control at 15 DAS. The effect of treatments on root and shoot weight was determined separately at 30 DAS. The most significant enhancement in root weight was found in the plants treated with MMRH22 (85\%), followed by a consortium (78\%) and RHPR20 (43\%), as compared to the uninoculated control. The treatment of plants with a consortium of RHPR20 + MMRH22 increased the shoot weights by 65\%, followed by RHPR20 (30\%) and MMRH22 (26\%). However, there was no significant difference in the number of leaves among all the treated and control plants. The enhancement of plant height by the treatment group over the control group was RHPR20 (52\%) > MMRH22 (23\%) > RHPR20 + MMRH22 (19\%) (Table 3). 


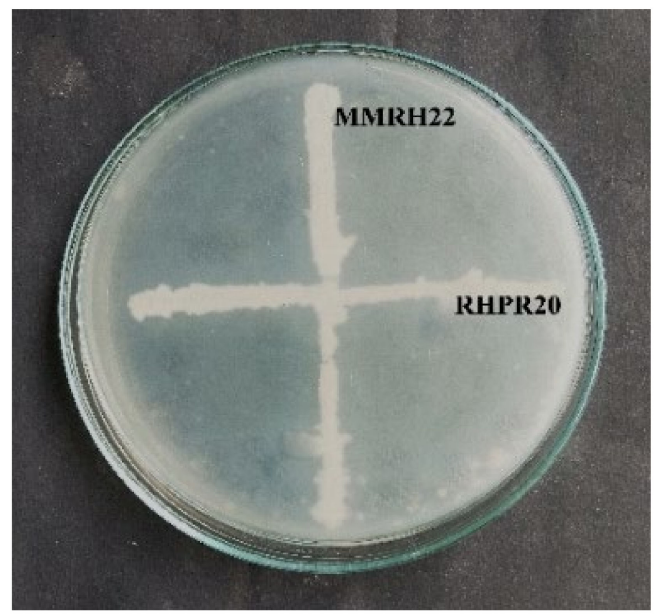

Figure 3. Compatibility of B. mojavensis RHR20 and B. cereus MMRH22 showing no zone of inhibition at the point of intersections.

Table 3. Sorghum plant growth on treatment with PGPB isolates at 30 DAS in greenhouse conditions.

\begin{tabular}{|c|c|c|c|c|c|c|}
\hline Treatment & $\begin{array}{c}\text { Plant } \\
\text { Height }(\mathrm{cm})\end{array}$ & $\begin{array}{c}\text { No of } \\
\text { Leaves }\end{array}$ & $\begin{array}{l}\text { Leaf Area } \\
\left(\mathrm{cm}^{2} / \text { Plant }\right)\end{array}$ & $\begin{array}{l}\text { Root Weight } \\
\text { (g/Plant) }\end{array}$ & $\begin{array}{l}\text { Shoot Weight } \\
\text { (g/Plant) }\end{array}$ & $\begin{array}{c}\text { Leaf Weight } \\
\text { (g/Plant) }\end{array}$ \\
\hline Bacillus mojavensis RHPR20 & 88 & 7 & 453 & 0.57 & 0.96 & 1.34 \\
\hline Bacillus cereus MMRH22 & 71 & 6 & 388 & 0.74 & 0.93 & 1.19 \\
\hline Consortia-RHPR20 + MMRH22 & 69 & 7 & 415 & 0.71 & 1.22 & 1.48 \\
\hline Control & 58 & 6 & 366 & 0.40 & 0.74 & 0.92 \\
\hline $\mathrm{SE} \pm$ & $1.5^{* * *}$ & $0.2^{* *}$ & 15.9 * & $0.05 * *$ & $0.06 * *$ & $0.09 *$ \\
\hline $\operatorname{LSD}(5 \%)$ & 5.3 & 0.6 & 55.2 & 0.17 & 0.20 & 0.33 \\
\hline $\mathrm{CV} \%$ & 4 & 5 & 7 & 14 & 10 & 13 \\
\hline
\end{tabular}

The data presented above is the average of three replications. LSD: Least significant difference; CV: Coefficient of variance; * Statistically significant at $0.05,{ }^{* *}$ Statistically significant at $0.01,{ }^{* * *}$ Statistically significant at 0.001 .

At 60 DAS, the highest plant height was found in the plants treated with the consortium RHPR20 + MMRH22 $(130 \mathrm{~cm})$, which followed by RHPR20 $(109 \mathrm{~cm})$ and MMRH22 $(106 \mathrm{~cm})$, whereas the untreated control measured only $58 \mathrm{~cm}$ (Table 4). Unlike the result at 30 DAS, there was a significant difference in the number of leaves at 60 DAS. The untreated plants had only 8 leaves, whereas the plants treated with RHPR20 had 10 leaves, and those treated with MMRH22 and the consortium MMRH22 + RHPR20 had 12 leaves each at 60 DAS (Table 4). In contrast, the root weight was higher in the plants treated with MMRH22 (4.16 g/plant). However, the highest shoot weight was observed in the plants treated with the consortium RHPR20 + MMRH22 (6.2 g/plant). The leaf weight was also highest in the plants treated with MMRH22 + RHPR20 (7.97 g/plant) (Table 4). In contrast to the previous observations (i.e., those at 30 and 60 DAS), all the parameters were found to be enhanced in the plants treated with a consortium of MMRH22 + RHPR20, as compared to the untreated control at final harvest (Table 5).

Table 4. Sorghum plant growth treatment with PGPB isolates at 60 DAS in greenhouse conditions.

\begin{tabular}{ccccccc}
\hline Treatment & $\begin{array}{c}\text { Plant } \\
\text { Height } \mathbf{( c m )}\end{array}$ & $\begin{array}{c}\text { No of } \\
\text { Leaves }\end{array}$ & $\begin{array}{c}\text { Leaf Area } \\
(\mathbf{c m} \text { /)/pl) }\end{array}$ & $\begin{array}{c}\text { Root Weight } \\
\text { (g/pl) }\end{array}$ & $\begin{array}{c}\text { Shoot Weight } \\
(\mathbf{g} / \mathbf{p l})\end{array}$ & $\begin{array}{c}\text { Leaf Weight } \\
\mathbf{( g / p l )}\end{array}$ \\
\hline Bacillus mojavensis RHPR20 & 109 & 10 & 1310 & 3.32 & 6.15 & 6.58 \\
Bacillus cereus MMRH22 & 106 & 12 & 1101 & 4.16 & 5.81 & 5.86 \\
Consortia-RHPR20 + MMRH22 & 130 & 12 & 1015 & 2.63 & 6.20 & 7.97 \\
Control & 83 & 8 & 382 & 2.25 & 2.25 & 2.18 \\
SE \pm & $2.6^{* * *}$ & $0.2^{* * *}$ & $41.4^{* * *}$ & $0.169^{* * *}$ & $0.205^{* * *}$ & $0.216^{* * *}$ \\
LSD (5\%) & 9.1 & 0.7 & 143.2 & 0.585 & 0.710 & 0.746 \\
CV\% & 4 & 4 & 8 & 10 & 7 & 7 \\
\hline
\end{tabular}

The data is the average of six replications. LSD: Least significant difference; CV: Coefficient of variance; ${ }^{* * *}$ Statistically significant at 0.001. 
Table 5. Sorghum plant growth on treatment with PGPB isolates at final harvest in greenhouse conditions.

\begin{tabular}{|c|c|c|c|c|c|}
\hline Treatment & $\begin{array}{c}\text { Panicle } \\
\text { Length }(\mathrm{cm})\end{array}$ & $\begin{array}{c}\text { Panicle Weight } \\
\text { (g/Plant) }\end{array}$ & $\begin{array}{l}\text { Seed Weight } \\
\text { (g/Plant) }\end{array}$ & $\begin{array}{l}\text { Shoot Weight } \\
\text { (g/Plant) }\end{array}$ & $\begin{array}{l}\text { Root Weight } \\
\text { (g/Plant) }\end{array}$ \\
\hline Bacillus mojavensis RHPR20 & 15.2 & 7.95 & 6.96 & 11.52 & 6.38 \\
\hline Bacillus cereus MMRH22 & 15.3 & 7.90 & 6.60 & 11.60 & 8.49 \\
\hline Consortia-RHPR20 + MMRH22 & 16.9 & 9.79 & 8.54 & 13.45 & 9.31 \\
\hline Control & 9.5 & 3.64 & 3.05 & 7.27 & 2.98 \\
\hline $\mathrm{SE} \pm$ & $0.39^{* * *}$ & $0.298^{* * *}$ & $0.305^{* * *}$ & $0.503^{* * *}$ & $0.542^{* * *}$ \\
\hline LSD (5\%) & 1.17 & 0.898 & 0.918 & 1.517 & 1.633 \\
\hline $\mathrm{CV} \%$ & 7 & 10 & 12 & 11 & 20 \\
\hline
\end{tabular}

The data is the average of six replications. LSD: Least significant difference; CV: Coefficient of variance; ${ }^{* * *}$ Statistically significant at 0.001.

\subsection{Root Colonization by Bacillus spp.}

The co-inoculation of the two Bacillus strains used in this study has aided in effective root colonization (as evident in Figure 4) of sorghum when compared to the inoculation with the individual strains (RHPR20 or MMRH22). However, no significant colonization was evident in the uninoculated control (Figure 4).

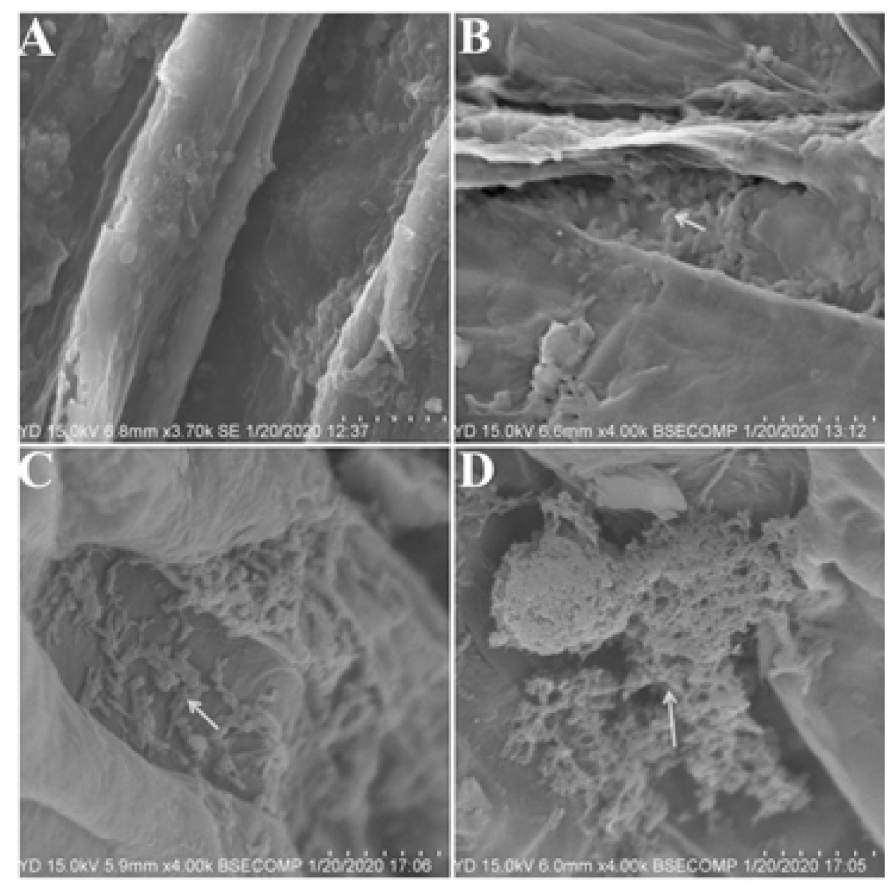

Figure 4. Scanning electron micrograph of PGPB-treated sorghum roots (A) Uninoculated control; (B-D) are treated with RHPR20, MMRH22, and RHPR20 + MMRH22, respectively. Arrow marks indicate root colonization by bacterial treatments.

\subsection{Estimation of Iron ( $\mathrm{Fe}$ ) Content of Sorghum Grains}

The uptake of iron in sorghum grains was varied according to the different treatments used in this study. The highest iron content was found in the grains of plants treated with the consortia (100.9 ppm), followed by MMRH22 (87.5 ppm) and RHPR20 (78.1 ppm) over the uninoculated control (51 ppm) (Figure 5). The maximum enhancement in Fe content (up to 97.8\%) was with the consortium RHPR20 + MMRH22, as compared to the uninoculated control. Among the four treatments, the iron content in the sorghum treated with the co-inoculation of strains RHPR20 and MMRH22 was significant, as compared to the uninoculated control. 


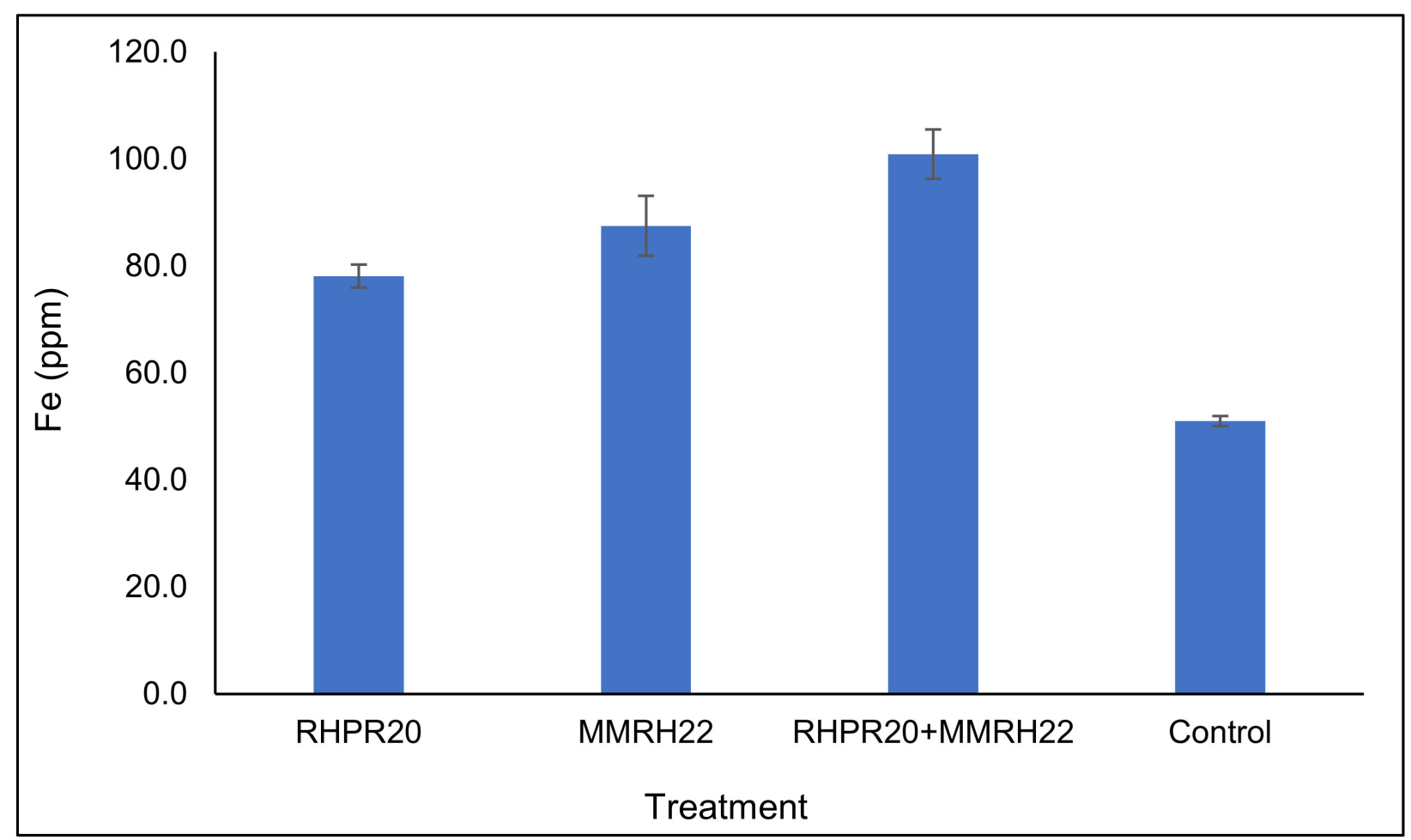

Figure 5. Iron $(\mathrm{Fe})$ content in sorghum grains obtained from plants grown with PGP bacterial treatment of seeds.

\section{Discussion}

Iron plays a crucial role in the metabolic processes of almost all living organisms. It is also a prosthetic group for most enzymes and activates several metabolic processes. The primary cause of iron deficiency is an imbalance between the demand of plants and the availability in the soil. Many reports have documented siderophore producers as bioinoculants for the promotion of plant growth and the control of phytopathogens, and this function is gradually being accepted. The characterization of plant growth-promoting bacteria should be attributed to the production of a wide range of metabolites such as IAA, ammonia, organic acids, hydrolytic enzymes, and ACC deaminase [33]. Based on their ability to survive and their compatibility with other bacteria, these microbes flourish together in the soil. These characteristics have prompted researchers to evaluate co-inoculation and, as a result, have been studied on various crops [34-36].

PGPR, which produces IAA, induces primary root elongation and the formation of lateral roots that enables the plant to absorb more nutrients. In a previous study, IAA that produces Bacillus mojavensis PB-35(R11), which is antagonistic to Rhizoctonia solani, produced $29 \mu \mathrm{g} / \mathrm{mL}$ of IAA [37], whereas the Bacillus spp. used in our study produced a higher amount. IAA-producing bacteria solubilized phosphate in the present study, as was evidenced by the halo zone forming around the colonies. Phosphate-solubilizing bacteria enhance the phosphorous-uptake in plants by increasing the bioavailability of phosphorous in the soil through various mechanisms of solubilization and mineralization [38,39]. Grover et al. [40] reported that phosphate-solubilizing Bacillus spp. enhanced the growth of sorghum under moisture-stress conditions. Earlier findings by Prakash and Arora [41] reported that IAA-producing, phosphate-solubilizing Bacillus spp. enhanced the plant growth and the oil yield of Mentha arvensis. Likewise, zinc plays a crucial role in plant growth, chlorophyll synthesis, and the development of chloroplasts [42]. Previous works have mentioned that Bacillus spp. can solubilize zinc $[22,43]$ and enhance plant growth, which can be associated with the zinc solubilization caused by the strains RHPR20 and MMRH22, which were used in this study. In the present study, all the isolates showed positive for the production of ammonia. The accumulation of ammonia alters the soil's $\mathrm{pH}$ 
to alkaline and, thereby, inhibits the germination of fungal spores and the suppression of phytopathogenic fungi [44]. Our study confirmed the variations in the production of ACC deaminase and the hydrolytic enzymes, such as protease, cellulase, and amylase, among the isolates used in the study (Tables 1 and 2). The production of hydrolytic enzymes by PGPR enables the recruitment of a beneficial microbial community in the rhizosphere that promotes plant growth and biocontrol $[45,46]$. PGPR are known to modulate plant growth and decrease ethylene production as a result of their ACC deaminase activity [47]. In a previous study, Mukhtar et al. [48] found that treatment with Bacillus cereus, which produced ACC deaminase, protease, and amylase, enhanced the growth of tomatoes under abiotic conditions. In our study, all the tested Bacillus spp. had the ability to produce siderophores that could aid plant growth directly by supplying iron to plants as well as indirectly by limiting iron's access to pathogens residing in the rhizosphere. Several strains of Bacillus subtilis have been reported to suppress fungal pathogens in plants using siderophores [37,49,50]. Hassan et al. [51], Akhtar et al. [52], and Niu et al. [53] documented plant growth promotion, the reduction of metal toxicity, and the defense response-ability of Bacillus cereus. Similar plant growth promotion and biocontrol activities of Bacillus mojavensis were reported by Prajakta et al. [37] and Rath et al. [54]. Despite many studies that have reported on plant growth promotion of several crops using rhizosphere bacteria, soil contamination by various salts and toxic substances could limit the efficacy of this PGP bacteria. Therefore, the development of novel microbial mixtures that can alleviate the growth and nutrient uptake of plants in varied environments is necessary. Marine microorganisms can adapt to a wide range of temperature fluctuations, salinity, osmotic pressure, and $\mathrm{pH}[55,56]$. In the present study, Bacillus mojavensis RHPR20 and Bacillus cereus-MMRH22 were compatible with each other. Our results are similar to results obtained by Prasad and Babu [30], where compatibility was tested between Azospirillum brasilense and Pseudomonas fluorescens for the plant growth promotion of groundnuts. Several studies reported the use of the consortia of various bacterial mixtures for plant growth promotion, nutrient enhancement, abiotic stress management, and biocontrol activities [35,55-58].

Though the Bacillus strains were compatible with each other in vitro, their performance during co-inoculation on plants may vary. The results obtained under greenhouse study corroborated with previous reports of Alekhya and Gopalakrishnan [31], where Streptomyces spp. promoted the plant growth of sorghum. In another study, He et al. [34] reported an increase in the growth, yield, and nutrient uptake of tomato on co-inoculation of Bacillus sp. and Pseudomonas sp. at different plant developmental stages. This might be another reason that co-inoculation showed better results after 60 DAS. In a study, Guo et al. [59] demonstrated the application of a consortium of three PGPR strains Bacillus cereus AR156, Bacillus subtilis SM21, and Serratia sp. XY21 to suppress sweet pepper disease. Our finding that a consortium of marine and rhizosphere Bacillus strains promoted sorghum growth is consistent with Saleemi et al. [60], who reported plant growth promotion of wheat using a consortium of rhizobial and phosphate solubilizing bacteria. Root colonization, plant growth promotion, and biological control against Fusarium wilt were observed when Bacillus amyloliquefaciens NJN-6 was inoculated in banana plants [61].

Inoculating plant growth-promoting bacteria enables plants to absorb more nutrients and moisture from the soil [2]. A previous study by Ali et al. [62] illustrated the enhancement of iron content in mungbean grains when a foliar spray of $\mathrm{FeSO}_{4}$ was applied. Whereas, in our study, the enhancement of iron content in the sorghum was obtained by the co-inoculation of Bacillus strains with various plant growth-promoting abilities, which can be used as bioinoculants that do not require any chemicals. Our study exemplified the work in plant-microbe interactions, focusing on iron biofortification in staple food crops (sorghum). Hence, producing future biofortified crops using PGP from varied sources should be an essential criterion to attain sustainable agriculture. 


\section{Conclusions}

Our results showed that Bacillus spp. isolated from various origins can synergistically enhance the growth and the uptake of iron content of sorghum. To our knowledge, this is the first report to enumerate the differences among isolates obtained from various origins in the plant growth promotion and the biofortification of sorghum. As evidenced by SEM observations, the isolates exhibited multiple plant growth-promoting traits and can colonize sorghum plant roots. Although the study was not conducted under field conditions, results revealed that the isolates could enhance the growth, the yield, and the iron content in sorghum grains, thus reducing malnutrition. Nevertheless, further work on the bioformulations of Bacillus strains under different environmental and field conditions would ensure the use of these strains to address iron deficiency in plants and human beings. The development of such beneficial microbial consortia could promote their application as potential bioinoculants for biofortification.

Author Contributions: Conceptualization, M.M. and B.H., methodology, resources, S.G., P.R. and V.S., Supervision, S.G.; Writing-Original draft, B.H., S.G., V.S., R.Z.S., Writing-Review and editing M.Y., H.A.E.E., A.T.K.Z. and H.S.K. Fund acquisition, H.S.K., H.A.E.E. and A.T.K.Z. All authors have read and agreed to the published version of the manuscript.

Funding: This research was funded by Researchers Supporting Project Number (RSP- 2021/403), King Saud University, Riyadh, Saudi Arabia, SERB-EMR, DST, Government of India for financial support [EMR/2016/003586(SERB/F/942/2017-2020)] and RMC, Universiti Teknologi Malaysia (UTM), and the support from the industrial grant RJ13000.7609.4C359 and RJ13000.7609.4C336.

Institutional Review Board Statement: Not Applicable.

Informed Consent Statement: Not Applicable.

Data Availability Statement: All the data is available in the manuscript file.

Acknowledgments: The authors extend their sincere appreciation to Researchers Supporting Project Number (RSP- 2021/403), King Saud University, Riyadh, Saudi Arabia, PVS Prasad, ICRISAT, India, and Prof. Gopal Reddy at Osmania University, Hyderabad, India.

Conflicts of Interest: The authors declare no conflict of interest.

\section{References}

1. Saltzman, A.; Andersson, M.S.; Asare-Marfo, D.; Lividini, K.; De Moura, F.F.; Moursi, M.; Oparinde, A.; Taleon, V. Biofortification techniques to improve food security. In Reference Module in Food Science; Elseveir: Amsterdam, The Netherlands, 2016; pp. 1-9. [CrossRef]

2. Shaikh, S.S.; Sayyed, R.Z.; Reddy, M.S. Plant growth-promoting rhizobacteria: An eco-friendly approach for sustainable agroecosystem. In Plant, Soil, and Microbes; Springer: Cham, Switzerland, 2016; pp. 181-201. [CrossRef]

3. Char, S.N.; Wei, J.; Mu, Q.; Li, X.; Zhang, Z.J.; Yu, J.; Yang, B. An agrobacterium-delivered CRISPR/Cas9 system for targeted mutagenesis in sorghum. Plant Biotechnol. J. 2020, 18, 319. [CrossRef]

4. Aruna, C.; Visarada, K.; Bhat, B.V.; Tonapi, V.A. Breeding Sorghum for Diverse End Uses; Woodhead Publishing: Amsterdam, The Netherlands, 2018.

5. Stamenković, O.S.; Siliveru, K.; Veljković, V.B.; Banković-Ilić, I.B.; Tasić, M.B.; Ciampitti, I.A.; DJalović, I.G.; Mitrović, P.M.; Sikora, V.Š.; Prasad, P.V. Production of biofuels from sorghum. Renew. Sustain. Energy Rev. 2020, 124, 109769. [CrossRef]

6. Mukisa, I.M.; Ntaate, D.; Byakika, S. Application of starter cultures in the production of Enturire-A traditional sorghum-based alcoholic beverage. Int. J. Food Sci. Nutr. 2017, 5, 609-616. [CrossRef]

7. Taylor, J.R.; Duodu, K.G. Sorghum and millets: Grain-quality characteristics and management of quality requirements. In Cereal Grains; Assessing and Managing Quality; Elsevier: Amsterdam, The Netherlands, 2017; pp. 317-351. [CrossRef]

8. Sayyed, R.Z.; Seifi, S.; Patel, P.R.; Shaikh, S.S.; Jadhav, H.P.; El Enshasy, H. Siderophore production in groundnut rhizosphere isolate, Achromobacter Sp. RZS2 influenced by physicochemical factors and metal ions. Environ. Sustain. 2019, 2, 117-124. [CrossRef]

9. Hafeez, F.Y.; Abaid-Ullah, M.; Hassan, M.N. Plant growth-promoting rhizobacteria as zinc mobilizers: A promising approach for cereals biofortification. In Bacteria in Agrobiology: Crop Productivity; Springer: Berlin/Heidelberg, Germany, 2013 ; pp. $217-235$. [CrossRef]

10. Zope, V.P.; El Enshasy, H.A.; Sayyed, R.Z. Plant growth-promoting rhizobacteria: An overview in agricultural perspectives. Plant Growth Promot. Rhizobacteria Sustain. Stress Manag. 2019, 345-361. [CrossRef] 
11. Basu, A.; Prasad, P.; Das, S.N.; Kalam, S.; Sayyed, R.Z.; Reddy, M.S.; El Enshasy, H. Plant growth promoting rhizobacteria (PGPR) as green bioinoculants: Recent developments, constraints, and prospects. Sustainability 2021, 13, 1140. [CrossRef]

12. Fazeli-Nasab, B.; Sayyed, R.Z. Plant growth-promoting rhizobacteria and salinity stress: A journey into the soil. In Plant Growth Promoting Rhizobacteria for Sustainable Stress Management; Springer: Singapore, 2019; pp. 21-34. [CrossRef]

13. Shaikh, S.S.; Wani, S.J.; Sayyed, R.Z. Statistical-based optimization and scale-up of siderophore production process on laboratory bioreactor. 3 Biotech 2016, 6, 69. [CrossRef]

14. Chbel, A.; Delgado, A.S.; Soukri, A.; El Khalfi, B. Marine Biomolecules: A promising approach in therapy and biotechnology. Eur. J. Biol. Res. 2021, 11, 122-133. [CrossRef]

15. Albdaiwi, R.N.; Khaymi-Horani, H.; Ayad, J.Y.; Alananbeh, K.M.; Kholoud, M.; Al-Sayaydeh, R. Isolation and characterization of halotolerant plant growth promoting rhizobacteria from durum wheat (Triticum turgidum subsp. durum) cultivated in saline areas of the Dead Sea region. Front. Microbiol. 2019, 10, 1639. [CrossRef] [PubMed]

16. Liu, Z.; Wang, H.; Xu, W.; Wang, Z. Isolation and evaluation of the plant growth promoting rhizobacterium Bacillus methylotrophicus (DD-1) for growth enhancement of rice seedling. Arch. Microbiol. 2020, 202, 2169-2179. [CrossRef] [PubMed]

17. Kushwaha, P.; Srivastava, R.; Pandiyan, K.; Singh, A.; Chakdar, H.; Kashyap, P.L.; Bhardwaj, A.K.; Murugan, K.; Karthikeyan, N.; Bagul, S.Y.; et al. Enhancement in plant growth and zinc biofortification of chickpea (Cicer arietinum L.) by Bacillus altitudinis. J. Soil Sci. Plant Nutr. 2021, 21, 922-935. [CrossRef]

18. Nithyapriya, S.; Lalitha, S.; Sayyed, R.Z.; Reddy, M.S.; Dailin, D.J.; El Enshasy, H.A.; Luh Suriani, N.; Herlambang, S. Production, purification, and characterization of bacillibactin siderophore of Bacillus subtilis and its application for improvement in plant growth and oil content in sesame. Sustainability 2021, 13, 5394. [CrossRef]

19. Prittesh, P.; Avnika, P.; Kinjal, P.; Jinal, H.N.; Sakthivel, K.; Amaresan, N. Amelioration effect of salt-tolerant plant growthpromoting bacteria on growth and physiological properties of rice (Oryza sativa) under salt-stressed conditions. Arch. Microbiol. 2020, 202, 2419-2428. [CrossRef] [PubMed]

20. Bhattacharjya, S.; Chandra, R. Effect of inoculation methods of Mesorhizobium ciceri and PGPR in chickpea (Cicer areietinum L.) on symbiotic traits, yields, nutrient uptake and soil properties. Legum. Res.-Int. J. 2013, 36, 331-337.

21. Nautiyal, C.S. An Efficient microbiological growth medium for screening phosphate solubilizing microorganisms. FEMS Microbiol. Lett. 1999, 170, 265-270. [CrossRef]

22. Bhatt, K.; Maheshwari, D.K. Decoding multifarious role of cow dung bacteria in mobilization of zinc fractions along with growth promotion of C. annuum L. Sci. Rep. 2019, 9, 1-10. [CrossRef] [PubMed]

23. Nuntagij, A.; Abe, M.; Uchiumi, T.; Seki, Y.; Boonkerd, N.; Higashi, S. Characterization of Bradyrhizobium strains isolated from soybean cultivation in Thailand. J. Gen. Appl. Microbiol. 1997, 43, 183-187. [CrossRef]

24. Kumar, G.P.; Desai, S.; Amalraj, L.; Reddy, G. Isolation of fluorescent Pseudomonas Spp. from diverse agro-ecosystems of India and characterization of their PGPR traits. Bacteriol. J. 2015, 5, 13-24. [CrossRef]

25. Lorck, H. Production of hydrocyanic acid by bacteria. Physiol. Plant. 1948, 1, 142-146. [CrossRef]

26. Ali, S.Z.; Sandhya, V.; Rao, L.V. Isolation and characterization of drought-tolerant ACC Deaminase and exopolysaccharideproducing fluorescent Pseudomonas Sp. Ann. Microbiol. 2014, 64, 493-502. [CrossRef]

27. Schwyn, B.; Neilands, J.B. Universal chemical assay for the detection and determination of siderophores. Anal. Biochem. 1987, 160, 47-56. [CrossRef]

28. Hendricks, C.W.; Doyle, J.D.; Hugley, B. A new solid medium for enumerating cellulose-utilizing bacteria in soil. Appl. Environ. Microbiol. 1995, 61, 2016-2019. [CrossRef] [PubMed]

29. Hasan, M.M.; Marzan, L.W.; Hosna, A.; Hakim, A.; Azad, A.K. Optimization of some fermentation conditions for the production of extracellular amylases by using Chryseobacterium and Bacillus isolates from organic kitchen wastes. J. Genet. Eng. Biotechnol. 2017, 15, 59-68. [CrossRef]

30. Prasad, A.A.; Babu, S. Compatibility of Azospirillum brasilense and Pseudomonas fluorescens in growth promotion of groundnut (Arachis hypogea L.). An. Acad. Bras. Cienc. 2017, 89, 1027-1040. [CrossRef] [PubMed]

31. Alekhya, G.; Gopalakrishnan, S. Plant growth-promotion by Streptomyces Spp. in sorghum (Sorghum bicolor L.). Afr. J. Biotechnol. 2016, 15, 1781-1788. [CrossRef]

32. Association of Analytical Chemists. Official Methods of Analysis (AOAC); AOAC International: Gaithersburg, MD, USA, 2000.

33. Pandey, S.; Gupta, S. ACC Deaminase producing bacteria with multifarious plant growth promoting traits alleviates salinity stress in French bean (Phaseolus vulgaris) plants. Front. Microbiol. 2019, 10, 1506. [CrossRef]

34. He, Y.; Pantigoso, H.A.; Wu, Z.; Vivanco, J.M. Co-Inoculation of Bacillus Sp. and Pseudomonas putida at different development stages acts as a biostimulant to promote growth, yield and nutrient uptake of tomato. J. Appl. Microbiol. 2019, 127, $196-207$. [CrossRef]

35. Jabborova, D.; Wirth, S.; Kannepalli, A.; Narimanov, A.; Desouky, S.; Davranov, K.; Sayyed, R.Z.; El Enshasy, H.; Malek, R.A.; Syed, A. Co-Inoculation of rhizobacteria and biochar application improves growth and nutrients in soybean and enriches soil nutrients and enzymes. Agronomy 2020, 10, 1142. [CrossRef]

36. Izquierdo-García, L.F.; González-Almario, A.; Cotes, A.M.; Moreno-Velandia, C.A. Trichoderma virens Gl006 and Bacillus velezensis Bs006: A compatible interaction controlling Fusarium wilt of Cape gooseberry. Sci. Rep. 2020, 10, 1-13. [CrossRef] 
37. Prajakta, B.M.; Suvarna, P.P.; Raghvendra, S.P.; Alok, R.R. Potential biocontrol and superlative plant growth promoting activity of indigenous Bacillus mojavensis PB-35 (R11) of soybean (Glycine max) rhizosphere. SN Appl. Sci. 2019, 1, 1143. [CrossRef]

38. Sharma, S.B.; Sayyed, R.Z.; Sonawane, M.; Trivedi, M.H.; Thivakaran, G.A. Neurospora Sp. SR8, a novel phosphate solubiliser from rhizosphere soil of sorghum in Kachchh, Gujarat, India. Indian J. Exp. Biol. 2016, 54, 644-649.

39. Kour, D.; Rana, K.L.; Yadav, A.N.; Yadav, N.; Kumar, V.; Kumar, A.; Sayyed, R.Z.; Hesham, A.E.-L.; Dhaliwal, H.S.; Saxena, A.K. Drought-tolerant phosphorus-solubilizing microbes: Biodiversity and biotechnological applications for alleviation of drought stress in plants. In Plant Growth-Promoting Rhizobacteria for Sustainable Stress Management; Springer: Singapore, 2019; pp. 255-308. [CrossRef]

40. Grover, M.; Madhubala, R.; Ali, S.Z.; Yadav, S.K.; Venkateswarlu, B. Influence of Bacillus Spp. strains on seedling growth and physiological parameters of sorghum under moisture stress conditions. J. Basic Microbiol. 2014, 54, 951-961. [CrossRef] [PubMed]

41. Prakash, J.; Arora, N.K. Phosphate-solubilizing Bacillus Sp. enhances growth, phosphorus uptake and oil yield of Mentha arvensis L. 3 Biotech 2019, 9, 1-9. [CrossRef]

42. Sharma, A.; Patni, B.; Shankhdhar, D.; Shankhdhar, S.C. Zinc-an indispensable micronutrient. Physiol. Mol. Biol. Plants 2013, 19, 11-20. [CrossRef] [PubMed]

43. Hussain, A.; Arshad, M.; Zahir, Z.; Asghar, M. Prospects of zinc solubilizing bacteria for enhancing growth of Maize. Pak. J. Agric. Sci. 2015, 52, 915-922.

44. Swamy, M.K.; Akhtar, M.S.; Sinniah, U.R. Response of PGPR and AM fungi toward growth and secondary metabolite production in medicinal and aromatic plants. In Plant, Soil, and Microbes; Springer: Cham, Switzerland, 2016; pp. 145-168. [CrossRef]

45. Shaikh, S.S.; Sayyed, R.Z. Role of plant growth-promoting rhizobacteria and their formulation in biocontrol of plant diseases. In Plant Microbes Symbiosis: Applied Facets; Springer: New Delhi, India, 2015; pp. 337-351. [CrossRef]

46. Jadhav, H.P.; Shaikh, S.S.; Sayyed, R.Z. Role of hydrolytic enzymes of rhizoflora in biocontrol of fungal phytopathogens: An overview. In Rhizotrophs: Plant Growth Promotion to Bioremediation; Springer: Singapore, 2017; pp. 183-203. [CrossRef]

47. Sagar, A.; Sayyed, R.Z.; Ramteke, P.W.; Sharma, S.; Marraiki, N.; Elgorban, A.M.; Syed, A. ACC Deaminase and antioxidant enzymes producing halophilic Enterobacter Sp. PR14 promotes the growth of Rice and Millets under salinity stress. Physiol. Mol. Biol. Plants 2020, 26, 1847-1854. [CrossRef] [PubMed]

48. Mukhtar, T.; Smith, D.; Sultan, T.; Seleiman, M.F.; Alsadon, A.A.; Ali, S.; Chaudhary, H.J.; Solieman, T.H.; Ibrahim, A.A.; Saad, M.A. Mitigation of heat stress in Solanum lycopersicum L. by ACC-deaminase and exopolysaccharide producing Bacillus cereus: Effects on biochemical profiling. Sustainability 2020, 12, 2159. [CrossRef]

49. Verma, J.P.; Jaiswal, D.K.; Krishna, R.; Prakash, S.; Yadav, J.; Singh, V. Characterization and screening of thermophilic Bacillus Strains for developing plant growth promoting consortium from Hot Spring of Leh and Ladakh region of India. Front. Microbiol. 2018, 9, 1293. [CrossRef]

50. Haddoudi, I.; Cabrefiga, J.; Mora, I.; Mhadhbi, H.; Montesinos, E.; Mrabet, M. Biological control of Fusarium Wilt caused by Fusarium equiseti in Vicia faba with broad spectrum antifungal plant-associated Bacillus Spp. Biol. Control. 2021, 104671. [CrossRef]

51. HASSAN12, T.U.; Bano, A.; Naz, I.; Hussain, M. Bacillus cereus: A competent plant growth promoting bacteria of saline sodic field. Pak. J. Bot. 2018, 50, 1029-1037.

52. Akhtar, N.; Ilyas, N.; Yasmin, H.; Sayyed, R.Z.; Hasnain, Z.; Elsayed, E.A.; El Enshasy, H.A. Role of Bacillus cereus in improving the growth and phytoextractability of Brassica nigra (L.) K. Koch in chromium contaminated soil. Molecules 2021, 26, 1569. [CrossRef]

53. Niu, D.-D.; Wang, C.-J.; Guo, Y.-H.; Jiang, C.-H.; Zhang, W.-Z.; Wang, Y.; Guo, J.-H. The plant growth-promoting rhizobacterium Bacillus cereus AR156 induces resistance in tomato with induction and priming of defence response. Biocontrol. Sci. Technol. 2012, 22, 991-1004. [CrossRef]

54. Rath, M.; Mitchell, T.R.; Gold, S.E. Volatiles produced by Bacillus mojavensis RRC101 act as plant growth modulators and are strongly culture-dependent. Microbiol. Res. 2018, 208, 76-84. [CrossRef]

55. Olanrewaju, O.S.; Babalola, O.O. Bacterial consortium for improved Maize (Zea mays L.) production. Microorganisms 2019, 7, 519. [CrossRef] [PubMed]

56. Shilev, S.; Babrikova, I.; Babrikov, T. Consortium of plant growth-promoting bacteria improves Spinach (Spinacea oleracea L.) growth under heavy metal stress conditions. J. Chem. Technol. Biotechnol. 2020, 95, 932-939. [CrossRef]

57. Kapadia, C.; Sayyed, R.Z.; El Enshasy, H.A.; Vaidya, H.; Sharma, D.; Patel, N.; Malek, R.A.; Syed, A.; Elgorban, A.M.; Ahmad, K. Halotolerant microbial consortia for sustainable mitigation of salinity stress, growth promotion, and mineral uptake in tomato plants and soil nutrient enrichment. Sustainability 2021, 13, 8369. [CrossRef]

58. Hussain, A.; Ahmad, M.; Nafees, M.; Iqbal, Z.; Luqman, M.; Jamil, M.; Maqsood, A.; Mora-Poblete, F.; Ahmar, S.; Chen, J.-T. Plant growth promoting Bacillus and Paenibacillus species improve the nutritional status of Triticum aestivum L. PLoS ONE 2020, 15, e0241130. [CrossRef]

59. Guo, J.H.; Zhang, L.; Wang, D.; Hu, Q.; Dai, X.; Xie, Y.; Li, Q.; Liu, H. Consortium of plant growth-promoting rhizobacteria strains suppresses sweet pepper disease by altering the rhizosphere microbiota. Front. Microbiol. 2019, 10, 1668. [CrossRef]

60. Saleemi, M.; Kiani, M.Z.; Sultan, T.; Khalid, A.; Mahmood, S. Integrated effect of plant growth promoting rhizobacteria and phosphate-solubilizing microorganisms on growth of Wheat (Triticum aestivum L.) under rainfed conditions. Agric. Food Secur. 2017, 6, 1-8. [CrossRef] 
61. Yuan, J.; Ruan, Y.; Wang, B.; Zhang, J.; Waseem, R.; Huang, Q.; Shen, Q. Plant growth promoting rhizobacteria strain Bacillus amyloliquefaciens NJN-6 enriched bio-organic fertilizer suppressed Fusarium Wilt and promoted the growth of Banana plants. J. Agric. Food chem. 2013, 61, 3774-3780. [CrossRef] [PubMed]

62. Ali, B.; Ali, A.; Tahir, M.; Ali, S. Growth, seed yield and quality of Mungbean as influenced by foliar application of iron sulfate. Pak. J. Life Soc. Scis. 2014, 12, 20-25. 